\title{
Stochastic Modeling of Flow and Sediment of the Rivers at Delta Head, East Coast of India
}

\author{
Siba Prasad Mishra \\ Department of Civil Engineering, Centurion University of Technology and Management, Odisha, India \\ Email: 2sibamishra@gmail.com
}

How to cite this paper: Mishra, S.P. (2017) Stochastic Modeling of Flow and Sediment of the Rivers at Delta Head, East Coast of India. American Journal of Operations Research, 7, 331-347.

https://doi.org/10.4236/ajor.2017.76025

Received: August 8, 2017

Accepted: October 15, 2017

Published: October 18, 2017

Copyright (c) 2017 by author and Scientific Research Publishing Inc. This work is licensed under the Creative Commons Attribution International License (CC BY 4.0).

http://creativecommons.org/licenses/by/4.0/

(c) (i) Open Access

\begin{abstract}
Major peninsular rivers debouching into the Bay of Bengal through $2729 \mathrm{~km}$ long east coast of India, carry enormous inland flow and sediment from their alluvial basins. Present climate changes, storm irregularities and tsunamis have changed the hydrology of the coastal rivers. The hydrologic interventions for human need have reduced the sediment flow of the rivers resulting in sinking the deltas. Twelve important river basins in the east coast of India were identified. Linear and nonlinear regression equations were developed by stochastic approach of their annual flow (1986-2011) and yearly sediment influx (1993-2012) for the 12 rivers at their delta head. As results, the annual flow of the rivers from Subarnarekha to Godavari followed rational curves except the Brahmani River and Gaussian models for rivers from the Godavari to south except the river Vaigai. Similarly, the curve fitting models of time series for sediment had shown a change in curve pattern, the river Godavari being the line of demarcation. Gumbel II and Log Pearson type III methods were used to predict the flow and the sediment at various probabilities. Sediment prediction by Gumbel method had shown lower values than Log Pearson Type III methods for planning and design of hydraulic structures. The disparities in geologic formation of the central India and Deccan Plateau can be emphasized based on the statistical interpretations.
\end{abstract}

\section{Keywords}

East Coast, Indian River, Regression Analysis, Gumbel II Method, LPT III Methods

\section{Introduction}

The Central Water Commission (CWC) of India has classified rivers in India based on their Catchment area as major (>20,000 sqkm), medium (2000 - 20,000 
sqkm) and minor (<2000 sqkm). India has 12 major, 46 medium and 14 minor and desert flowing river basins comprising of areas $252.8 \mathrm{MH}, 24.6 \mathrm{MH}$ and 110 $\mathrm{MH}$ respectively (CWC Hand Book 2005) [1]. All peninsular rivers are either west or east flowing in India. The major east flowing rivers are the Subarnarekha, the Mahanadi, the Godavari, the Krishna, the Cauvery and the Vaigai. Large, medium and small prominent rivers debouching in Bay of Bengal are about 88 numbers (Table 1). The length of east coast (EC) is $2729 \mathrm{~km}$ from the river Hooghly (north) to Tambaraparani (south) (Figure 1).

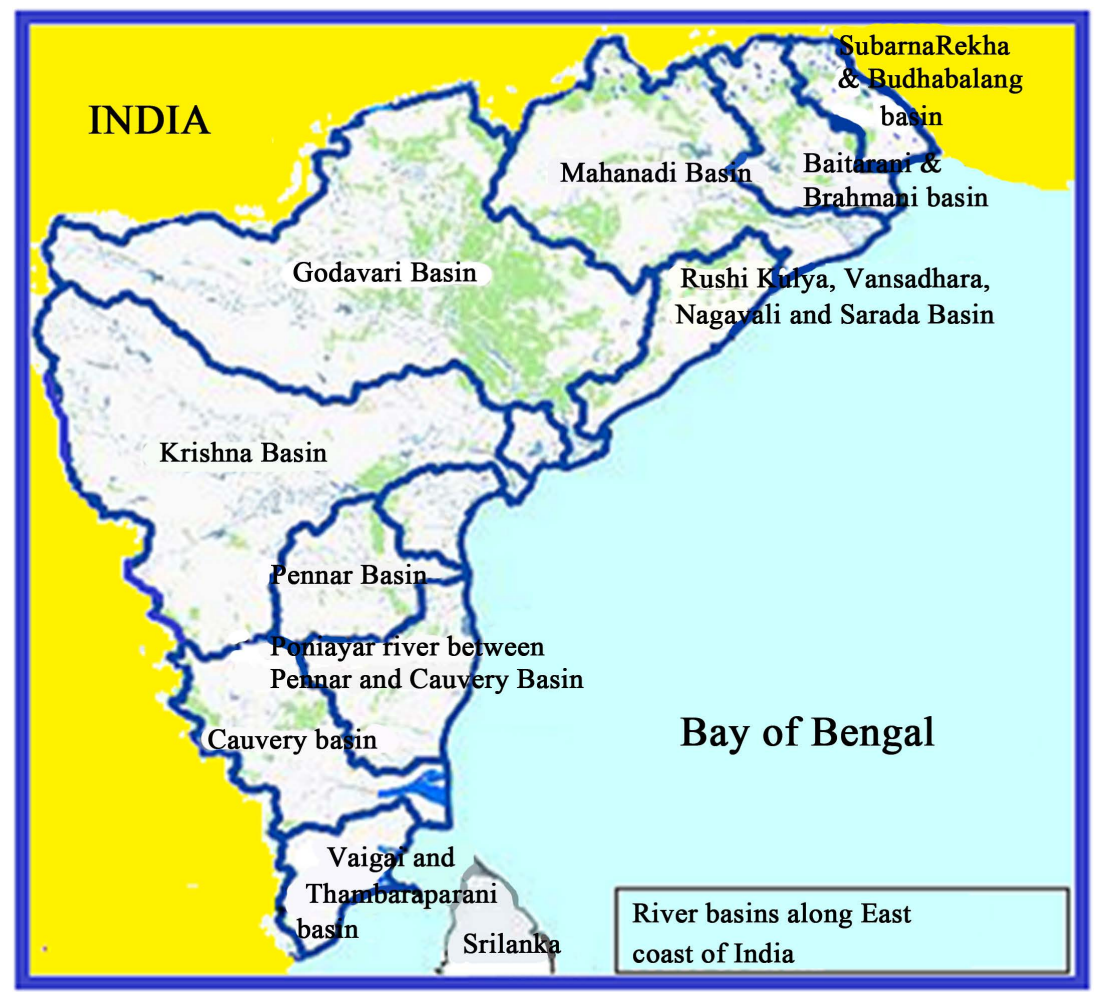

Figure 1. Major basins in east coast of India. Source: NRSC, Bhuvan, Hyd.

Table 1. The rivers and the lagoons that transport sediment to Bay of Bengal.

\begin{tabular}{|c|c|c|c|}
\hline Sl & State & $\begin{array}{l}\text { Name of drainage channels }(\mathrm{d} / \mathrm{c} \text { 's }) \\
\text { joining BOB via a lagoon }\end{array}$ & Name of the rivers and distributaries directly joining Bay of Bengal \\
\hline 1 & West Bengal & - & Haladi, Rupnarain, Damodar, Rasulpur, Mandarmani \\
\hline 2 & Odisha & $\begin{array}{l}\text { Chilika lake: Daya, } \\
\text { Bhargovi, Salia (Four inlets) }\end{array}$ & $\begin{array}{l}\text { Subarnarekha, Jambhira, Budhabalanga, Baitarani (Dhamara), } \\
\text { Bramhani, Mahanadi, Devi, Kusha-bhadra, Rushikulya, Bahuda }\end{array}$ \\
\hline 3 & $\begin{array}{l}\text { Andhra } \\
\text { Pradesh }\end{array}$ & $\begin{array}{l}\text { Kolleru: Budameru, Tamileru, } \\
\text { Gaderu (connected by } 68 \text { drains bet. } \\
\text { Krishna and Godavari, Iskapalli, } \\
\text { Vallederu (T. I. one) Kuratipalem) }\end{array}$ & $\begin{array}{l}\text { Vamsdhra, Nagavai, Peddagedda, Kandivalasa, Nelhmaria, Gosiani, } \\
\text { Narayagida, Sarada, Varaha, Tandava, Eluru, Godavari, Krishna, } \\
\text { Gundlakamma, Musi, Palleru, Manneru, Penneru, Upputeru, Swarnamukhi }\end{array}$ \\
\hline 4 & Tamilnadu & $\begin{array}{l}\text { Pulikat: Arani, Kalangi and } \\
\text { swarnmukhi rivers } \\
\text { (T.I.: Tupilipalem, } \\
\text { Rayadoruvu and Pulicat villages) }\end{array}$ & $\begin{array}{l}\text { Arni, Cooum, Adyar, Palar, Chunnambar, Uppar, } \\
\text { Vellar, Kollidam (Coleroon), Kaveri, Varshalee, } \\
\text { Manimuttar, Vaigai, Vaippar Chittar, Thamarparani }\end{array}$ \\
\hline 5 & Puduchery & & Arya Kupam, Mallatar, Ginjer, Ponnaiyar, Godilam \\
\hline
\end{tabular}


The Subarnarekha, the northern most east flowing peninsular river, is originating from rifts of the Chota Nagpur Hills (lat $23^{\circ} 18^{\prime} \mathrm{E}$ and long $85^{\circ} 11^{\prime} \mathrm{N}$ ). The small river, Thamarparani in extreme south starts from the Western Ghats (lat $8^{\circ} 46^{\prime} \mathrm{E}$ and long $77^{\circ} 15^{\prime} \mathrm{N}$ ) near Vana-theertham waterfalls near Agastyarkoodam peak of Western Ghats in Ambasamudram district.

The east flowing rivers originate from eastern side of the Western Ghats range and flow through the basalts of the Deccan plateau. They take course along the Deccan traps and crosses through the gorges of the Eastern Ghats belt to join the Bay of Bengal.

The lengths of east flowing ephemeral rivers are long and catchment areas of these basins are large with wide deltas than that of West Coast Rivers. The east coast is emergent whereas the west coast submerging. They carry huge sediment to form large deltas. The longest river is the Godavari $(1465 \mathrm{~km})$ of catchment area $312,812 \mathrm{~km}^{2}$ (Figure 2) which carries average annual flow of 83.94 Bcum at deltahead (till 1986-2011) and average sediment influx from the basin (45.5 MMT till 1993-2012) (Table 2).

East coast of India is extending from Kanya Kumari in south to Haladia port in north with a continental shelf of area 22,411 sqkm up to $50 \mathrm{~m}$., Kulkarni et al., (1985) [2]. It has five coastal states having coastal length i.e. West Bengal (158 $\mathrm{km})$, Orissa $(480 \mathrm{~km})$, Andhra Pradesh $(974 \mathrm{~km})$ and Tamil Nadu $(1076 \mathrm{~km})$ and Pondicherry Union Territory $(41 \mathrm{~km})$. Rivers joining the Bay of Bengal in West Bengal are either from NW or north. The mega cities along East Coast are Calcutta, Vishakhapatnam and Chennai etc. Indian rivers carry $1645 \times 10^{9} \mathrm{~km}^{3}$

Table 2. The major 12 rivers along EC of India and their length, area, time series for sediment and flow (source: CWC Integrated Hand book 2005, 2006, 2009, 2012 and 2015) [30].

\begin{tabular}{|c|c|c|c|c|c|c|c|c|}
\hline $\begin{array}{l}\text { River } \\
\text { No }\end{array}$ & $\begin{array}{l}\text { Name } \\
\text { of River }\end{array}$ & $\begin{array}{l}\text { Length } \mathrm{Km} / \text { Basin } \\
\text { catchment (sqkm) }\end{array}$ & (G \& D site) & $\begin{array}{l}\text { Catchment } \\
\text { upto delta } \\
\text { head (sqkm) }\end{array}$ & $\begin{array}{c}\text { Years of } \\
\text { flow Obsn. }\end{array}$ & $\begin{array}{c}\text { Av. annual } \\
\text { disch. (Bcum) }\end{array}$ & $\begin{array}{c}\text { Years of } \\
\text { sediment } \\
\text { Obsn. }\end{array}$ & $\begin{array}{l}\text { Av sed } \\
(\mathrm{MMT})\end{array}$ \\
\hline 1 & Subarnrekha & $446 / 19,277$ & Ghatsila & 14,176 & $1986-2011$ & 13.875 & $1993-2012$ & 2.64 \\
\hline 2 & Baitarani & $365 / 14,218$ & Anandpur & 8570 & $1991-2011$ & 4.79 & $1993-2012$ & 2.24 \\
\hline 3 & Brahmani & $799 / 39,116$ & Jenapur & 33,955 & $1986-2011$ & 17.433 & $1993-2012$ & 5.23 \\
\hline 4 & Mahanadi & $891 / 141,589$ & Tikarpada & 124,450 & $1986-2011$ & 46.969 & $1993-2012$ & 11.02 \\
\hline 5 & Vans-dhara & $254 / 10,830$ & Kasinagar & 7820 & $1986-2011$ & 2.896 & $1993-2012$ & 3.087 \\
\hline 6 & Godavari & $1465 / 312,812$ & Pollavaram & 307,800 & $1985-2011$ & 83.942 & $1993-2012$ & 45.57 \\
\hline 7 & Krishna & $1400 / 258,948$ & Agraharam/Vijaywada & 251,360 & $1985-2011$ & 26.048 & $1993-2012$ & 5.145 \\
\hline 8 & Pennar & $597 / 55,213$ & Nellore (Musiri) & 50,800 & 1989-2011 & 1.299 & 1991-2012 & 1.157 \\
\hline 9 & Ponnaiyar & $400 / 16,019$ & Gumanur & 4620 & 1989-1998 & 0.653 & 1991-2012 & 0.357 \\
\hline 10 & Cauvery & $765 / 81,155$ & Kodumudi & 66,243 & $1989-2011$ & 8.185 & $1993-2012$ & 0.326 \\
\hline 11 & Vaigai & $240 / 7741$ & Ambasamudram & 3721 & $\begin{array}{l}1989-1999 \\
2007-2011\end{array}$ & 0.053 & 2003-2012 & 0.073 \\
\hline 12 & $\begin{array}{c}\text { Thambar } \\
\text { parani }\end{array}$ & $130 / 5482$ & Murapandu & 4380 & $\begin{array}{l}1989-1999 \\
2007-2011\end{array}$ & 0.551 & $1991-2012$ & 0.044 \\
\hline
\end{tabular}




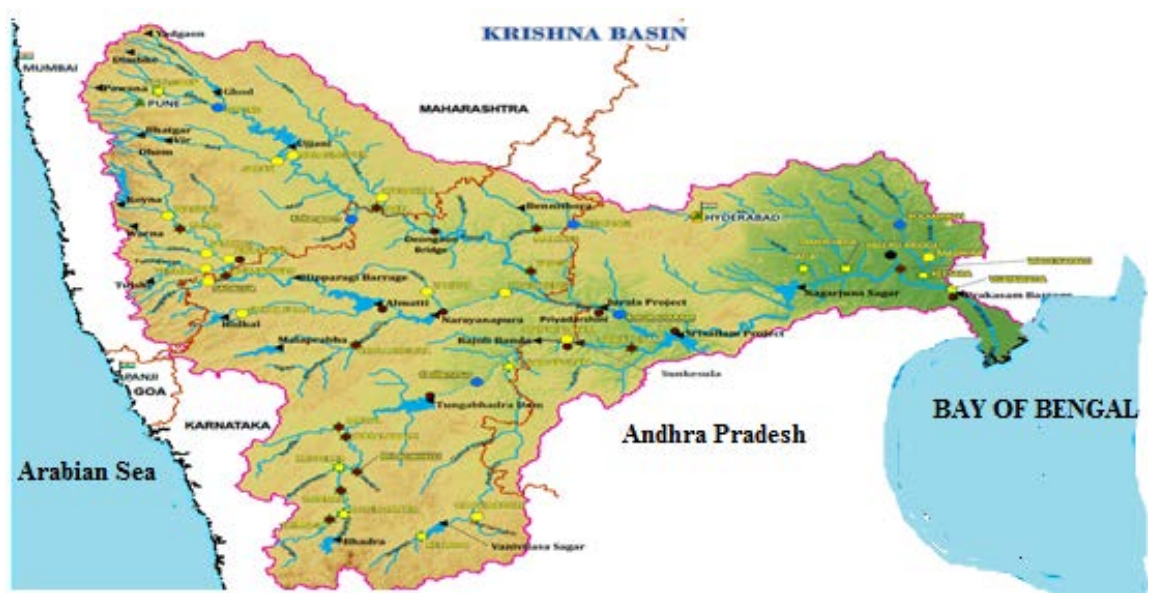

Krishna Basin

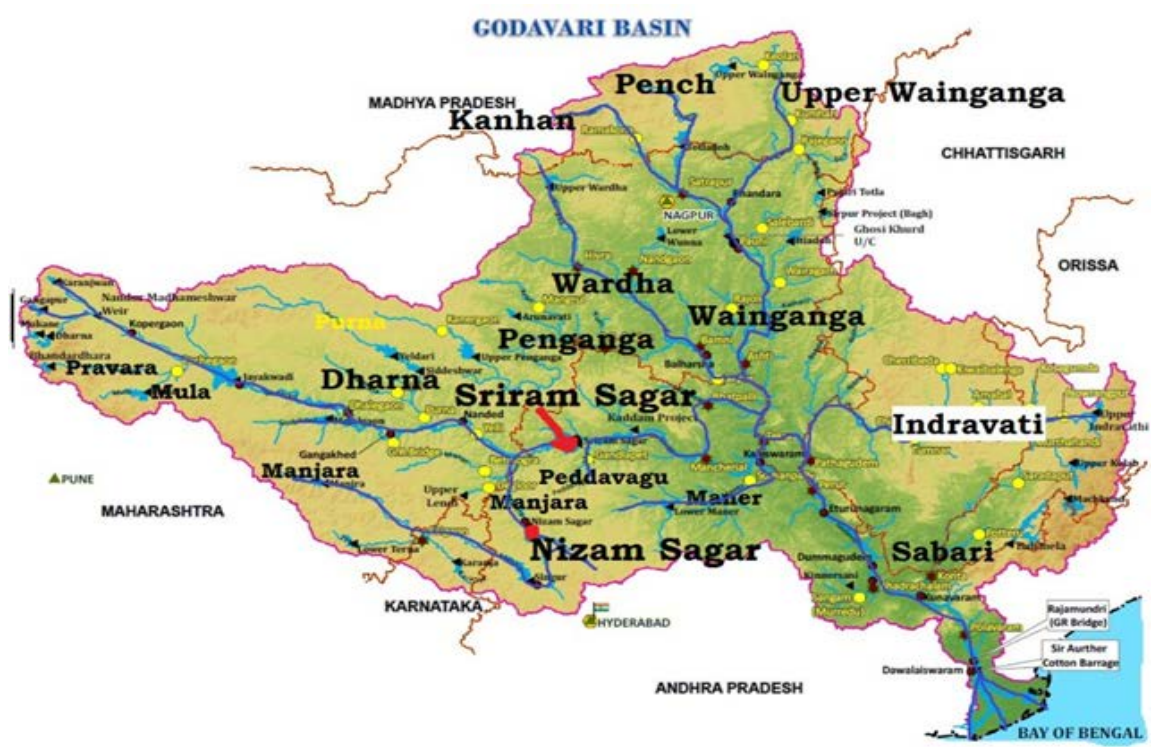

Godavari Basin

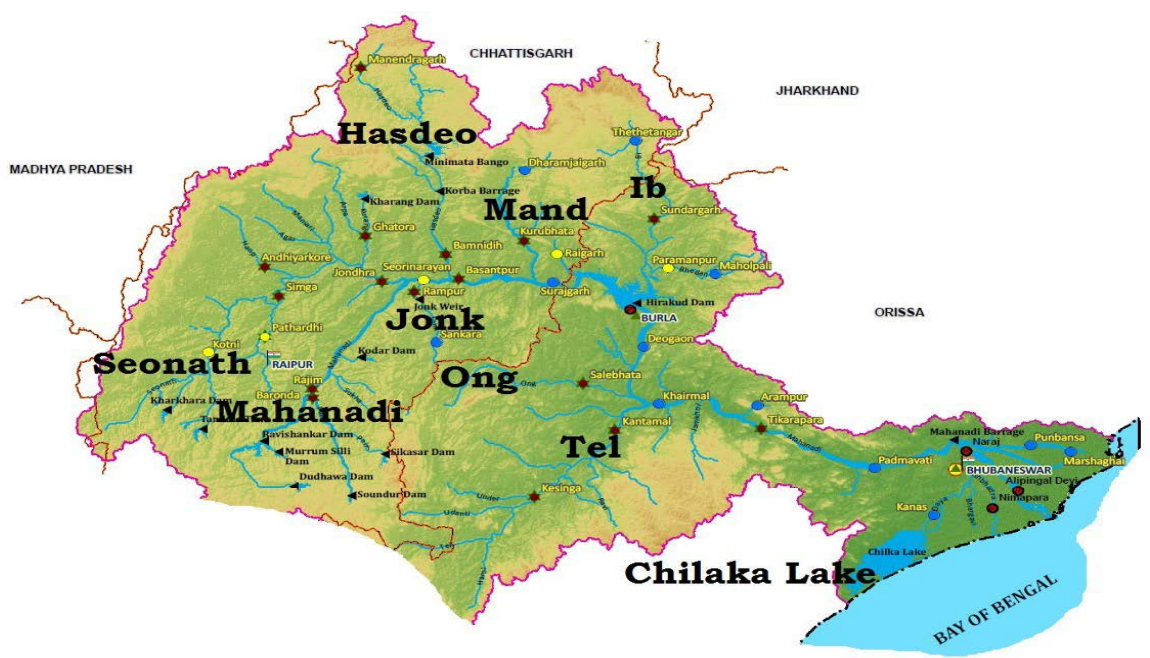

Mahanadi Basin

Figure 2. Three large basins of the rivers Mahanadi, the Godavari and Krishna in east coast of India. 
of water with huge quantities of sediment in average $1.2 \times 10^{12} \mathrm{~kg}$ to sea which is one tenth of sediment flux of the globe Chandra Mohan et al. (2001) [3].

The climate of the region is subtropical to tropical. The temperature of the basin area is in average $18^{\circ} \mathrm{C}$ to $45^{\circ} \mathrm{C}$ with rainfall ranging from $1400-1500 \mathrm{~mm}$ in northern part and $900-1000 \mathrm{~mm}$ in the southern region of EC of India. The South West monsoon (JJAS months) and North East monsoon (Nov. and Dec.) influence the quantity of rainfall of the area. The rivers in south of the Godavari basin receives rainfall from both the south west monsoon and north east monsoon. The east flowing rivers to the north of the Godavari basin receives rainfall from the south west monsoon. The Bay of Bengal disturbances through the Odisha coast (48.2\%), West Bengal coast (25.5\%, Andhra coast (19.3\%) and Tamilnadu coast (6.7\%) Mohapatra et al., 2010 [4].

The East coast of India and the adjoining Bay of Bengal was rifted from Antarctica during the early Cretaceous period (65.5 Mya BP). The conjugate oceanic crust of the Bay of Bengal was assumed to be between Ender Bay basin and East Antarctica. Fuloria et al. 2014 [5], described a major fault separate the Ganga basin from the Mahanadi basin. The Visakhapatnam high separates the Mahanadi from the Godavari and the highs of Naidupeta and Chingle put between the Krishna and the Cauvery basins in the peninsular India (Figure 2). The rivers took thousands of years to manifest by deposition in layers of clastic sediments till extinction of prolonged volcanic activities.

Tandon et al., 2007 [6] reported the high sediment flux in the peninsular rivers in India are not the outcrop of recent tectonic setting like Himalayan rivers but due to the result of tropical weathering of rocks in their basin. Lal et al. 2009 [7], identified four stages of formation of the east coast of India which was Cretaceous origin but large modifications occurred during Quaternary period due to global cooling and warming. Dune dynamics and reactivation along coast have changed the river dynamics from late Holocene to recent. Deltaic Changes of river course were identified geospatially in Odisha, Andhra and Tamilnadu coasts (Mahalik et al. (2006) [8], Kumaran et al. (2012) [9], Kakani et al. (2003) [10], Prabakaran et al. 2010 [11] and Sundaresh et al., 2014 [12].

\section{Review of Literature}

The suspended sediment (coarse, medium and silt loads) are $90 \%$ of the total annual sediment load which is carried by the flood flow $\mathrm{d} / \mathrm{s}$ to Bay retaining only $10 \%$ behind the water resources structures. Dams (Major, Medium and minor) and BWA's (barrages, weirs and anicuts) in Odisha constructed along these rivers are 180 and 43 respectively (INDIA-WRIS WIKI-2014) [13]. Increased anthropogenic activities with natural processes have accelerated the sediment fluxes in the sea Milliman et al. 1992 [14], Syvitsky et al. (1999) [15]. The net effect of sediment load changes on the global land-ocean sediment flux suggests that the "natural" or "pre-human" flux has been almost doubled by anthropogenic impacts. But $50 \%$ of the gross flux has been trapped in reservoirs, Zhou Zhide et al. 2015 [16]. 
The deltas of rivers are sinking, shrinking and under subsidence due to anthropologic interventions like dams and BWA's. Sediment studies have been done by various authors like Gamage et al. (2009) [17], Rao et al. (2010) [18] Syvitski et al. (2009) [19], (2011) [20], Gupta et al. (2012) [21] and Dandekar (2014) [22] for only east flowing large rivers in India, like the Ganges, Mahanadi, the Godavari, the Krishna and the Cauvery but not for rivers of small catchment. The coastal plains of E.C. of India grow deltas by the sediments of the major rivers, but some patches are of Aeolian and marine origin. There are seven important deltas in the east coast, namely the Subarnarekha, the Mahanadi, the Godavari, the Krishna, the Penner and the Cauvery host estuaries with dense mangroves reported by Kumaran et al., 2012 [8].

Sanil Ku. V. et al., 2006 [23] reported that shoreline along east coast oscillate and seasonal. The places where the cycle of one oscillation is not complete within a year the beach suffer from net erosion and vice versa. Ports and harbours suffer from erosion to its north as a result of the construction of breakwaters as sedimentation is not allowed.

Nnaji et al. 2014 [24], reported Gumbel and Log Pearson Type III (LPT III) and Weibull distributions can reasonably predict of flow frequency. LPT III distribution can be provided and more appropriate. Vogel R. A, (1993) [24] reported LPT III method of flood flow modeling was recommended by United states as flood frequency guide lines. The Gumbel method of prob. distribution model accepted by chi-square goodness of fit tests was considered as the best model in the Seyhan river Teheran, Topaloglu (2002) [25], Luo P. et al., 2013 [26] classified rivers into three parts basing on the quantum of suspended sediment and the found the R2 values of the time series. Solomon et al., 2013 [27], considered Gumbel method of distribution was suitable for predicting expected flow of the river OSSE, Argentina. Ghosh K. G. et al. 2015 [28] reported that after construction of dam and barrages flood frequency have raised and analysis of the flood frequency by LPT III method is acceptable. Mishra et al. 2015 [29], reported Gumbel and LPT III methods can be used for probabilistic prediction of monsoon rainfall in the Mahanadi basin.

Less research work have been done on the sediment flow of small river basin. This paper is an attempt to study the water and the sediment flow in 12 major rivers flowing into the Bay of Bengal along east coast of India at their delta head.

\section{Methods}

Spatiotemporal trends of annual discharge of (monsoon + non-monsoon) flow and sediment were collected from Integrated Hydrological data book (non-classified basins), 2005, 2006, 2009, 2012 and 2015 of Central Water Commission, Government of India [30]. The annual flow and corresponding sediment data was considered of the stations at the delta head of the twelve rivers. The data for the major 12 major and medium rivers debouching Bay of Bengal were compiled as a time series and analyzed (Figure 3). The rate of suspended 


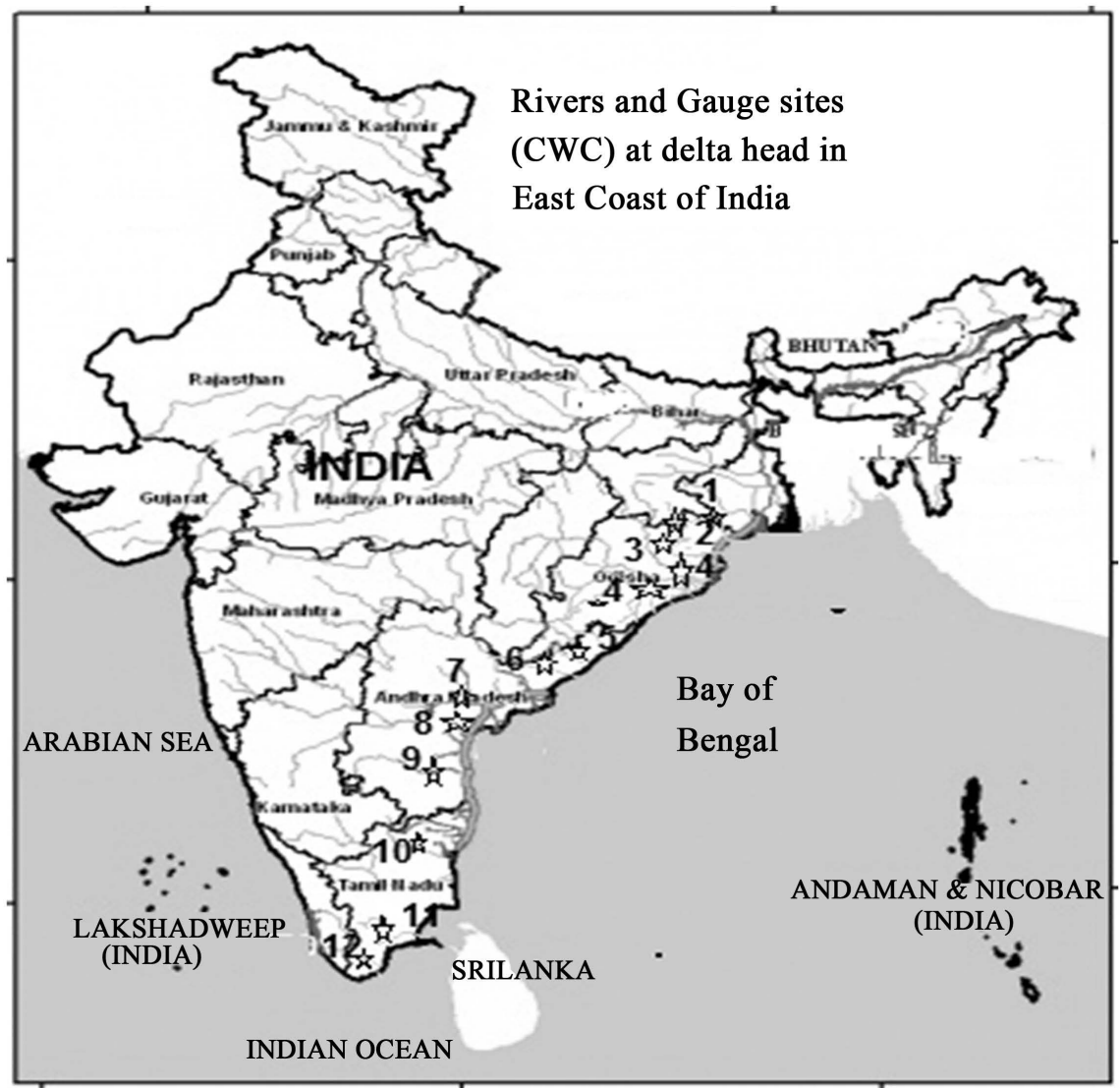

Figure 3. Rivers and their Gauge sites along east coast of India as per Table 1.

sediment discharge against annual flow and their trend with time were studied. The linear and nonlinear regression equations of the twelve rivers were developed using different curves such as polynomial, sigmoid, peak, power, logarithm, rational and wave form by the statistical tools and EXCEL methods and others. The equations that had highest $R^{2}$ value $(>60 \%)$ were considered as the fitted curve.

Flood and sediment modeling and prediction were done by deterministic modeling by using a long data series. Different models used are deterministic, stochastic, statistical or soft computing. Attempt has been made in this paper to predict the annual flow and corresponding sediment at various recurrence intervals though the time series length is short. The common statistical probability density functions used were Gumble, Log Pearson Type III (LPT III) and compared the results with their present trend.

\section{Methodology}

The annual time series data were collected to find a trend in the annual flow and the sediment influx and used to predict future values of the time series. Regression equations both linear and nonlinear equations used were polynomials, peak, sigmoid, wave form, power, exponential and rational etc. Correlation is done to test how closely the experimental data (Variables) are interdependent. The cor- 
relation coefficient and coefficient of determination were found to verify the reliability of the data.

\section{Correlation Coefficient $(R)$}

It is the data in a time series are linearly related the correlation coefficient $(r)$ is calculated by formulae

$$
r=\left[\sum d_{x} d_{y}\right] /\left[\sqrt{\sum d_{x^{2}} \sum d_{y^{2}}}\right]
$$

It is the ratio of standard deviation to covariance and how a time series close to the mean value of data series,

where

$$
\sum d_{x^{2}}=\sum x^{2}-\frac{\left(\sum x^{2}\right)}{n}, \sum d_{y^{2}}=\sum y^{2}-\frac{\left(\sum y^{2}\right)}{n}
$$

and

$$
\sum d_{x} d_{y}=\sum x y-\frac{\left(\sum x \sum y\right)}{n}
$$

where " $d$ " represents as the deviation from the mean. $R$ values lies between $-1<$ $R<1$. When $R$ is zero or near zero there is almost zero correlation, +1 is a perfect fit with same slope and the time series is positively and linearly related. For $\mathrm{R}$-values to be negative it indicates perfect negative fit with opposite slope and the series is not related. OR, the other form can be: The

$$
\text { Correlation Coefficient }=R=\sqrt{\left(1-\frac{\mathrm{SSE}}{\mathrm{SST}}\right)}
$$

where SSE is the sum of squares due to error and

$$
\mathrm{SST}=\sum \text { squared totals }=\sum\left(y_{i}-\bar{y}\right)^{2}
$$

where, $\bar{y}=$ mean value of the series $y$.

\section{Coefficient of determination $\left(R^{2}\right)$}

In a regression model the ratio of the variance of the fitted values to the observed values are called coefficient of determination. If $y_{i}$ is the observed value, $\bar{y}=$ mean value of the series $y$ and $\hat{y}_{i}$ is the fitted value then the coefficient of determination $=R^{2}=\frac{\sum\left(\hat{y}_{i}-\bar{y}\right)^{2}}{\sum\left(y_{i}-\bar{y}\right)^{2}}$ where, $R^{2}$ has values lies between 0 and 1 . Higher the $\mathrm{R}^{2}$ values better the result of the model and hence the prediction and the curve fitting. It indicates about $\%$ of data lies close to best fit line. Negative values of $\mathrm{R}^{2}$ indicate the regression equation does not fit the data.

The dimensions like shape, size, and flow parameters differ. The regression equations that fit the curve with highest $R^{2}$ values also differ from river to river. The common used statistical projections for annual flow and sediment were made by using Gumbel II or Log Pearson Type III methods for recurrence intervals $1.11,2,5,10,20,25,50,100 \cdots$ upto 10,000 years for 12 major rivers in Odisha, Andhra Pradesh, Puducherry and Tamil Nadu. 


\section{Discussion}

The rivers, their length, the location of the gauge and discharge site, the average annual flow and the average annual sediment of the twelve rivers are given in Table 2.

The total catchment area for the peninsular east flowing rivers debouching the Bay of Bengal upto their delta head found to be 0.97 million sqkm. The average annual flow, the corresponding average annual sediment flowing at the delta head of the rivers found to be 227.3 Billon Cum and 84.6 MMT respectively (About 10\% allowances provided for the small rivers and lagoons which are not considered).

\section{Regression Equations}

\subsection{Annual Flow Series (Curve Fitting)}

The annual flow for the largest and the longest 12small and large rivers in East coast of India were taken for the years 1986 to 2011. Various stochastic models tried and the curve fitting equations having highest $R^{2}$ values are given in Table 3.

Using methods of both linear and nonlinear regression techniques, fitted curves were tried. The equation of the curve considered to be the best fit whose coefficient of determination values $\left(\mathrm{R}^{2}\right)$ found to be the highest. From time series of annual flow for the northern east flowing rivers in India (the Subarnarekha to the Godavari) supports rational function whereas the small southern rivers (Krishna to Thambarparani) follows Gaussian or Lognormal distribution except the river Vaigai, The fittest distribution have high $\mathrm{R}^{2}$ values for the southern rivers than the northern rivers Table 3.

\subsection{Annual Sediment Series (Curve Fitting)}

The annual sediment flow for the largest and the longest 12small and large rivers in East coast of India were taken for the years 1993 to 2012. Various stochastic models tried and the curve fitting equations having highest $R^{2}$ values for the quantum of sediment flow in the rivers are given in Table 4.

On linear and nonlinear curve fitting, the annual sediment flow exhibit nonlinear correlation of Gaussian type and the coefficient of determination values have shown higher values 50\% - 99\% except rivers Brahmani and Godavari. Maximum numbers of large dams in the sub- basins of the river Godavari might not be giving $R^{2}$-value $<50 \%$ (Table 5 ). Both the rivers have surplus water potential considered by NWDA, the National Water Development agency (an agency to interconnect rivers of India).

\section{Estimation of Flow and Sediment}

Return period or recurrence interval ( $\mathrm{Tr}$ ) is the average interval of any event in the years equaling or exceeding a given magnitude. Probability exceedence $(p)$ is 
Table 3. The model fit to the time series for annual flow of the rivers (monsoon + non-monsoon) to Bay of Bengal (BoB) via East coast of India.

\begin{tabular}{|c|c|c|c|c|c|c|c|c|c|}
\hline \multirow{2}{*}{$\begin{array}{l}\text { Number } \\
\text { of river }\end{array}$} & \multirow{2}{*}{$\mathrm{PDF}$} & \multirow{2}{*}{ Equation } & \multicolumn{6}{|c|}{ Parameters for Equations } & \multirow{2}{*}{$\mathrm{R}^{2}$ in $\%$} \\
\hline & & & $y_{0}$ & $a$ & $b$ & $c$ & $d$ & $x_{0}$ & \\
\hline Subarnarekha & $\begin{array}{l}\text { Rational } \\
\quad(7 \mathrm{P})\end{array}$ & $Y=\frac{a+b x+c x^{2}+d x^{3}}{1+e x+f x^{2}+g x^{3}}$ & & 6.434 & -1.33 & 0.081 & $\begin{array}{c}d=-1.5 \mathrm{E}-7 \\
e=-0.20\end{array}$ & $\begin{array}{c}f=-0.012 \\
g=-2.2 \mathrm{E}-4\end{array}$ & 54 \\
\hline Baitarani & $\begin{array}{c}\log \\
\text { Normal }\end{array}$ & $Y=y_{0}+\frac{a}{x} \mathrm{e}^{\left[\begin{array}{c}\ln \frac{x}{x_{0}} \\
-0.5\end{array}\right]^{2}}$ & 2.88 & 42.2 & 0.05 & & & .17 .3 & 38 \\
\hline Brahmani & Sine $(4 \mathrm{P})$ & $Y=y_{0}+a \sin \left(\frac{2 \pi x}{b}+c\right)$ & 1.79 & 4.22 & 2.23 & 0.601 & & & 30 \\
\hline Mahanadi & $\begin{array}{l}\text { Rational } \\
\text { (6P) }\end{array}$ & $Y=\frac{a+b x+c x^{2}}{1+d x+e x^{2}+f x^{3}}$ & & 39.6 & -6.67 & -0.25 & $\begin{array}{c}d=-0.177 \\
e=0.008\end{array}$ & $f=-4.88 \mathrm{E}-5$ & 60 \\
\hline Vansadhara & $\begin{array}{l}\text { Damped } \\
\text { Sine }\end{array}$ & $Y=y_{0}+a \mathrm{e}^{-\frac{x}{d}} \sin \left[\frac{2 \pi(x)}{b}+c\right]$ & 2.76 & 1.52 & 1463 & 4.85 & 117.1 & & 36 \\
\hline Nagavali & $\begin{array}{l}\text { Rational } \\
\qquad(5 \mathrm{P})\end{array}$ & $Y=\frac{a+b x+c x^{2}}{1+d x+e x^{2}}$ & & 2.47 & -0.34 & 0.01 & $\begin{array}{l}d=-0.138 \\
e=0.0042\end{array}$ & & 43 \\
\hline Godavari & $\begin{array}{l}\text { Rational } \\
\quad(6 \mathrm{P})\end{array}$ & $Y=\frac{a+b x+c x^{2}}{1+d x+e x^{2}+f x^{3}}$ & & 108 & -17.7 & 0.52 & $\begin{array}{c}d=-0.139 \\
e=8.04 \mathrm{E}-5\end{array}$ & & 32 \\
\hline Krishna & $\begin{array}{c}\text { Gaus- } \\
\operatorname{sian}(\bmod )\end{array}$ & $Y=y_{0}+a \mathrm{e}^{0.5\left(\frac{x-x_{0}}{b}\right)^{c}}$ & 21.9 & 35.2 & 1.495 & 18.4 & & 21.47 & 50 \\
\hline Pennar & $\begin{array}{l}\text { Gaus- } \\
\operatorname{sian}(4 \mathrm{P})\end{array}$ & $Y=y_{0}+a \mathrm{e}^{0.5\left(\frac{x-x_{0}}{b}\right)^{2}}$ & 1.01 & 17.5 & 22.38 & & & 8.321 & 55 \\
\hline Ponniayar & $\begin{array}{l}\text { Weilbull } \\
\text { (5P) }\end{array}$ & $Y=y_{0}+\cdots+\frac{c-1}{c}$ & 0.38 & 5.7 & 1.35 & 4.87 & & 7.609 & 69 \\
\hline Cauvery & $\begin{array}{l}\text { Gaus- } \\
\operatorname{sian}(4 \mathrm{P})\end{array}$ & $Y=y_{0}+a \mathrm{e}^{0.5\left(\frac{x-x_{0}}{b}\right)^{2}}$ & 9.05 & -7.8 & 1.013 & 14.6 & & 4.11 & 46 \\
\hline Vaigai & $\begin{array}{l}\text { Rational } \\
\qquad(8 \mathrm{P})\end{array}$ & $Y=\frac{a+b x+c x^{2}+d x^{3}}{1+e x+f x^{2}+g x^{3}+h x^{4}}$ & & 0.02 & $-8 \mathrm{E}-2$ & $9 \mathrm{E}-4$ & $\begin{array}{c}\mathrm{d}=2.77 \mathrm{E}-5 \\
e=-0.446\end{array}$ & $\begin{array}{c}f=0.068 \\
g=-0.003 \\
h=5.15 \mathrm{E}-5\end{array}$ & 92 \\
\hline Tambarparani & $\begin{array}{c}\log \\
\text { Normal }\end{array}$ & $Y=y_{0}+\frac{a}{x} \mathrm{e}^{\left[\begin{array}{c}\ln \frac{x}{x_{0}} \\
-0.5\end{array}\right]^{2}}$ & 4.66 & 4.57 & 0.12 & & & 4.64 & 61 \\
\hline
\end{tabular}

Table 4. The model fit to the time series for sediment influx to BoB via the rivers in East Coast.

\begin{tabular}{|c|c|c|c|c|c|c|c|c|c|}
\hline \multirow{2}{*}{ River } & \multirow{2}{*}{$\mathrm{PDF}$} & \multirow{2}{*}{ Equation } & \multicolumn{6}{|c|}{ Parameters for Equations } & \multirow{2}{*}{$\mathrm{R}^{2}(\%)$} \\
\hline & & & $y_{0}$ & $a$ & $b$ & $c$ & $d$ & $x_{0}$ & \\
\hline Subarnarekha & Mod Gaussian & $Y=y_{0}+a \mathrm{e}^{0.5\left(\frac{x-x_{0}}{b}\right)^{c}}$ & 1.97 & 1.09 & 0.52 & 3.93 & & 1.561 & $54 \%$ \\
\hline $\begin{array}{l}\text { Budha } \\
\text { balanga }\end{array}$ & Mod damped Sine & $Y=a \mathrm{e}^{-\frac{x}{c}} \sin \frac{\pi\left(x-x_{0}\right)}{b}$ & & 1.99 & 8.96 & $1.37 \mathrm{E} 6$ & & -0.18 & $92 \%$ \\
\hline Brahmani & Inverse $3^{\text {rd }}$ order & $Y=y_{0}+\frac{a}{x}+\frac{b}{x^{2}}+\frac{c}{x^{3}}$ & 5.24 & 23.5 & 139 & -114.1 & & & $37 \%$ \\
\hline Mahanadi & Damped Sine & $Y=y_{0} a \mathrm{e}^{-\frac{x}{d}} \sin \left[\frac{2 \pi(x)}{b}+c\right.$ & 8.69 & 977 & 4.16 & 4.77 & 0.66 & & $86 \%$ \\
\hline
\end{tabular}




\section{Continued}

\begin{tabular}{|c|c|c|c|c|c|c|c|c|c|}
\hline Rushikulya & Mod Gaussian & $Y=y_{0}+a \mathrm{e}^{0.5\left(\frac{x-x_{0}}{b}\right)^{c}}$ & 1.26 & 4.23 & 1.11 & 8.026 & & 8.84 & $80 \%$ \\
\hline Vansadhara & Lorenzian (4P) & $Y=y_{0}+\frac{a}{1+\left[\frac{x-x_{0}}{b}\right]^{2}}$ & 2.15 & 13.3 & 0.49 & & & 15.34 & $58 \%$ \\
\hline Nagavali & Lorenzian (4P) & $Y=y_{0}+\frac{a}{1+\left[\frac{x-x_{0}}{b}\right]^{2}}$ & 0.54 & 9.96 & 0.86 & 1.347 & & 7.222 & $93 \%$ \\
\hline Godavari & Rational (10P) & $Y=\frac{a+b x+c x^{2}+d x^{3}}{1+f x+g x^{2}+h x^{3}+i x^{4}}$ & & 73.87 & -43.7 & 7.51 & $\begin{array}{l}d=-0.49 \\
e=0.011 \\
f=-0.50\end{array}$ & & $43 \%$ \\
\hline Krishna & Gaussian (4P) & $Y=y_{0}+a \mathrm{e}^{0.5\left(\frac{x-x_{0}}{b}\right)^{2}}$ & 11.5 & 177.2 & 0.37 & 4.11 & & & $73 \%$ \\
\hline Pennar & Gaussian (4P) & $Y=y_{0}+a \mathrm{e}^{0.5\left(\frac{x-x_{0}}{b}\right)^{2}}$ & 0.84 & 20.14 & 0.22 & & & 4.39 & $99 \%$ \\
\hline Ponniayar & Gaussian (3P) & $Y=a \mathrm{e}^{0.5\left(\frac{x-x_{0}}{b}\right)^{2}}$ & & 7.17 & 0.34 & & & 16.18 & $99 \%$ \\
\hline Cauvery & Gaussian (4P) & $Y=y_{0}+a \mathrm{e}^{0.5\left(\frac{x-x_{0}}{b}\right)^{2}}$ & 0.26 & 0.706 & 0.77 & & & 4.11 & $58 \%$ \\
\hline Vaigai & Gaussian (5P) & $Y=y_{0}+a \mathrm{e}^{0.5\left(\frac{x-x_{0}}{b}\right)^{c}}$ & 0.04 & 0.082 & 2.26 & 209.3 & & 4.628 & $57 \%$ \\
\hline Tambarparani & Gaussian (4P) & $Y=y_{0}+a \mathrm{e}^{0.5\left(\frac{x-x_{0}}{b}\right)^{2}}$ & 0.02 & 0.362 & 0.51 & & & 3.342 & $94 \%$ \\
\hline
\end{tabular}

Table 5. Estimation of annual total flow in east flowing rivers in EC of India (Gumbel II method).

\begin{tabular}{|c|c|c|c|c|c|c|c|c|c|c|c|c|}
\hline$\left(\mathrm{T}_{\mathrm{r}}\right)$ & Subarnarekha & Baitarani & Bramhani & Mahanadi & Vansadhara & Godavari & Krishna & Pennar & Ponniyar & Cauvery & Vaigai & Tambarparan \\
\hline & Bcum & Bcum & Bcum & Bcum & Bcum & Bcum & Bcum & Bcum & Bcum & Bcum & Bcum & Bcum \\
\hline 1.05 & 1.47 & 1.62 & 6.8 & 14.55 & 0.56 & 28.77 & 3.73 & -1.46 & -0.55 & 3.58 & 0.04 & 0.1 \\
\hline 1.11 & 2.43 & 2.15 & 8.48 & 19.98 & 0.95 & 38.19 & 7.47 & -0.99 & -0.37 & 4.35 & 0.04 & 0.18 \\
\hline 1.25 & 3.69 & 2.85 & 10.7 & 27.12 & 1.46 & 50.58 & 12.38 & -0.38 & -0.13 & 5.37 & 0.05 & 0.28 \\
\hline 2 & 6.63 & 4.47 & 15.85 & 43.72 & 2.66 & 79.39 & 23.8 & 1.03 & 0.42 & 7.73 & 0.08 & 0.51 \\
\hline 5 & 10.59 & 6.66 & 22.78 & 66.07 & 4.28 & 118.16 & 39.17 & 2.93 & 1.17 & 10.92 & 0.11 & 0.82 \\
\hline 10 & 13.21 & 8.11 & 27.37 & 80.86 & 5.34 & 143.83 & 49.34 & 4.2 & 1.66 & 13.02 & 0.13 & 1.03 \\
\hline 25 & 16.52 & 9.94 & 33.16 & 99.55 & 6.69 & 176.26 & 62.2 & 5.79 & 2.28 & 15.69 & 0.16 & 1.29 \\
\hline 50 & 18.97 & 11.29 & 37.46 & 113.42 & 7.69 & 200.32 & 71.73 & 6.97 & 2.75 & 17.66 & 0.18 & 1.48 \\
\hline 100 & 21.41 & 12.64 & 41.73 & 127.19 & 8.69 & 224.2 & 81.2 & 8.14 & 3.2 & 19.62 & 0.20 & 1.67 \\
\hline 200 & 23.84 & 13.98 & 45.99 & 140.90 & 9.68 & 248.00 & 90.63 & 9.31 & 3.66 & 21.58 & 0.22 & 1.87 \\
\hline 500 & 27.04 & 15.75 & 51.6 & 158.99 & 10.99 & 279.39 & 103.07 & 10.85 & 4.26 & 24.15 & 0.24 & 2.12 \\
\hline 1000 & 29.47 & 17.09 & 55.84 & 172.67 & 11.97 & 303.12 & 112.48 & 12.02 & 4.72 & 26.1 & 0.26 & 2.31 \\
\hline 2000 & 31.89 & 18.43 & 60.08 & 186.34 & 12.96 & 326.84 & 121.88 & 13.18 & 5.18 & 28.05 & 0.28 & 2.5 \\
\hline 5000 & 35.09 & 20.19 & 65.68 & 204.41 & 14.26 & 358.18 & 134.31 & 14.72 & 5.78 & 30.62 & 0.31 & 2.75 \\
\hline 10,000 & 37.5 & 21.53 & 69.92 & 218.07 & 15.25 & 381.89 & 143.7 & 15.89 & 6.23 & 32.57 & 0.33 & 2.94 \\
\hline
\end{tabular}


the chance that the annual event of any year will equal or exceed some given value. The probability $(P)$ of an event with recurrence interval $T$ is $P=1 / T$.

\subsection{Gumbel Method}

Gumbel method is one of the oldest methods for prediction of hydrologic data Al-Mashidani et al. 1978 [31]. This method is given by: $Q_{t}=\bar{Q}(1+K \sigma)$ Where $Q_{t}=$ the discharge at recurrence interval of T-years, $\bar{Q}$ and $\sigma$ are the mean of the observed time series discharge and standard deviation respectively. $K$ is the frequency factor found from Gumbel's table, where

$$
K=-\sqrt{6} / \pi(\lambda-\ln (\ln T-\ln (T-1)))
$$

where $\lambda$ is Euler's constant $=0.5772$. To test the goodness of fit $\chi^{2}$ test is conducted with hypothesis that the data fits Gumbel distribution and vice versa. (Never Mujere 2011) [32]. The estimations are done by using statistical Hydraulic package http://onlinecalc.sdsu.edu/textbookhydrologyp217.html.

From the future estimation of quantity of flow by Gumble II method in 12 major rivers in east coast of India at various recurrence intervals are observed. It is found that total annual discharge of the major rivers shall increase proportionately at higher return periods. There shall be years ahead when the monsoon shall be erratic and the rainfall/runoff shall have increasing tendency as flow prediction indicate irregularity Table 6.

Prediction of the annual sediment against various recurrence interval of the east flowing rivers in the east coast, it is ascertained that the sediment concentration/Bcum of inland inflow shall increase gradually and the delta building process shall be emerging Table 7 .

Table 6. Estimation of sediment in east flowing rivers in East coast of India (Gumbel II method).

\begin{tabular}{ccccccccccccccc}
\hline $\begin{array}{c}\text { Ret. } \\
\text { period } \\
\text { (yr) }\end{array}$ & Subarnarekha & Baitarani & Bramhani & Mahanadi & Vansadhara & Godavari & Krishna & Pennar & Ponniyar Cauvery & Vaigai & Tparani \\
\hline & MMT & MMT & MMT & MMT & MMT & MMT & MMT & MMT & MMT & MMT & MMT & MMT \\
2 & 2.20 & 1.77 & 4.66 & 9.33 & 2.10 & 41.98 & 4.44 & 0.98 & 0.05 & 0.27 & 0.05 & 0.02 \\
5 & 5.41 & 3.63 & 8.74 & 21.51 & 4.87 & 63.77 & 11.11 & 2.36 & 0.17 & 0.50 & 0.10 & 0.05 \\
10 & 7.54 & 4.94 & 11.43 & 29.58 & 7.26 & 77.47 & 15.52 & 3.27 & 0.24 & 0.66 & 0.15 & 0.09 \\
25 & 10.23 & 6.53 & 14.84 & 39.77 & 10.80 & 93.74 & 21.10 & 4.43 & 0.34 & 0.87 & 0.24 & 0.21 \\
50 & 12.23 & 7.63 & 17.37 & 47.33 & 13.74 & 105.07 & 25.23 & 5.28 & 0.41 & 1.02 & 0.32 & 0.35 \\
100 & 14.21 & 8.66 & 19.88 & 54.84 & 16.87 & 115.72 & 29.34 & 6.13 & 0.47 & 1.17 & 0.42 & 0.59 \\
200 & 16.18 & 9.59 & 22.38 & 62.31 & 20.21 & 125.84 & 33.43 & 6.98 & 0.54 & 1.31 & 0.54 & 0.96 \\
500 & 18.79 & 10.70 & 25.68 & 72.18 & 24.88 & 138.44 & 38.83 & 8.10 & 0.64 & 1.48 & 0.73 & 1.78 \\
1000 & 20.76 & 11.46 & 28.17 & 79.63 & 28.62 & 147.56 & 42.91 & 8.94 & 0.70 & 1.62 & 0.91 & 2.79 \\
2000 & 22.72 & 12.15 & 30.66 & 87.09 & 32.48 & 156.19 & 46.99 & 9.79 & 0.77 & 1.74 & 1.12 & 4.35 \\
5000 & 25.32 & 12.82 & 33.96 & 96.94 & 36.88 & 165.29 & 52.38 & 10.9 & 0.87 & 1.87 & 1.40 & 7.14 \\
10,000 & 27.29 & 13.51 & 36.45 & 104.4 & 41.92 & 174.97 & 56.46 & 11.75 & 0.93 & 2.01 & 1.76 & 11.7 \\
\hline
\end{tabular}


Table 7. Estimation of annual flow to BoB in major East Coast Rivers of India (LPT III method).

\begin{tabular}{|c|c|c|c|c|c|c|c|c|c|c|c|c|}
\hline $\begin{array}{c}\text { Return } \\
\text { period } \\
(\mathrm{yr})\end{array}$ & Subarnarekha & Baitarani & Bramhani & Mahanadi & Vansadhara & Godavari & Krishna & Pennar & Ponniyar & Cauvery & Vaigai & Thamarparani \\
\hline & Bcum & Bcum & Bcum & Bcum & Bcum & Bcum & Bcum & Bcum & Bcum & Bcum & Bcum & Bcum \\
\hline 1.05 & 2.56 & 1.78 & 0.67 & 23.79 & 0.87 & 39.09 & 6.71 & 0.02 & 0.04 & 2.98 & 0 & 0.23 \\
\hline 1.11 & 3.14 & 2.24 & 3.05 & 26.59 & 1.14 & 45.45 & 9.2 & 0.04 & 0.06 & 3.98 & 0 & 0.27 \\
\hline 1.25 & 4.02 & 2.91 & 10.76 & 30.72 & 1.55 & 54.6 & 13.07 & 0.09 & 0.1 & 5.39 & 0.01 & 0.32 \\
\hline 2 & 6.37 & 4.52 & 24.94 & 41.9 & 2.63 & 77.8 & 23.53 & 0.45 & 0.27 & 8.37 & 0.04 & 0.48 \\
\hline 5 & 9.93 & 6.57 & 22.33 & 59.82 & 4.13 & 111.25 & 38.04 & 1.97 & 0.73 & 11.09 & 0.1 & 0.74 \\
\hline 10 & 12.46 & 7.79 & 20 & 73.45 & 5.07 & 134.32 & 46.99 & 4.01 & 1.25 & 12.2 & 0.16 & 0.93 \\
\hline 25 & 15.79 & 9.16 & 19.23 & 92.8 & 6.17 & 164.4 & 57.24 & 8.22 & 2.24 & 13.07 & 0.24 & 1.2 \\
\hline 50 & 18.35 & 10.08 & 18.76 & 108.84 & 6.93 & 187.42 & 64.1 & 12.78 & 3.28 & 13.49 & 0.31 & 1.43 \\
\hline 100 & 20.98 & 10.91 & 18.89 & 126.35 & 7.64 & 210.94 & 70.32 & 18.73 & 4.63 & 13.76 & 0.37 & 1.67 \\
\hline 200 & 23.69 & 11.68 & 18.88 & 145.52 & 8.3 & 235.2 & 75.99 & 26.29 & 6.37 & 13.95 & 0.44 & 1.93 \\
\hline 500 & 27.39 & 12.6 & 18.87 & 173.79 & 9.11 & 268.41 & 82.71 & 39.02 & 9.41 & 14.12 & 0.53 & 2.32 \\
\hline 1000 & 30.3 & 13.25 & 18.87 & 197.61 & 9.69 & 294.59 & 87.34 & 51.06 & 12.4 & 14.2 & 0.6 & 2.64 \\
\hline 2000 & 33.3 & 13.84 & 18.87 & 223.79 & 10.23 & 321.79 & 91.58 & 65.26 & 16.2 & 14.26 & 0.66 & 2.99 \\
\hline 5000 & 36.79 & 14.45 & 18.87 & 256.95 & 10.79 & 353.7 & 95.77 & 83.87 & 21.5 & 14.29 & 0.73 & 3.42 \\
\hline 10,000 & 40.64 & 15.08 & 18.87 & 295.09 & 11.37 & 388.77 & 100.1 & 107.9 & 28.5 & 14.33 & 0.8 & 3.92 \\
\hline Skewness & -0.12 & -0.59 & -4.62 & 0.49 & -0.57 & 0.04 & -0.7 & -0.34 & 0.11 & -1.46 & -0.7 & 0.25 \\
\hline
\end{tabular}

\subsection{LPT III Method}

LPT III method is one of the commonly used method hydrologic frequency analysis. The method is extremely flexible Nnaji G. A. et al., 2014 [33]. When skewness coefficient become zero when the LPT III distribution reduced to lognormal distribution. LPT III distribution is calculated using equation

$$
\log x=\overline{\log x}+K \sigma_{\lg x}
$$

where $x$ is taken as annual flow or yearly sediment flow. $\overline{\log x}$ arithmetic mean of logarithm values of the variables $x$ and $K$ is the frequency factor found from the Log Pearson frequency factor table, and is the standard deviation of the logarithm values given by $\sigma_{\log x}=\frac{\left[\sqrt{\sum(\log x-\overline{\log x})}\right]}{n-1}$ and the results are shown in Table 7.

On analysis of annual flow series of major rivers in the east coast falling Bay of Bengal by LPT III it is observed that at 50 years return period Godavari shall increase in flow and shall have 108.84 Bcum whereas present annual average discharge was 83.942 Bcum. The river Brahmani shall show a constant average annual flow for the coming 10,000 years Figure 4 and Table 8. 
Table 8. Estimation of sediment influx to BoBin MMT different east flowing rivers in East coast of India (LPT III method).

\begin{tabular}{ccccccccccccc}
\hline R. period (yr) & Srekha & Baitarani & Bramhani & Mahanadi & Vansadhara & Godavari & Krishna & Pennar & Ponniyar & Cauvery & Vaigai & Tparani \\
\hline 2 & 1.44 & 1.77 & 4.64 & 7.81 & 2.10 & 41.98 & 2.58 & 0.72 & 0.02 & 0.27 & 0.05 & 0.02 \\
5 & 4.36 & 3.63 & 8.13 & 14.83 & 4.87 & 63.77 & 8.19 & 1.60 & 0.08 & 0.50 & 0.10 & 0.05 \\
10 & 7.20 & 4.94 & 10.10 & 21.51 & 7.26 & 77.47 & 14.55 & 2.54 & 0.17 & 0.66 & 0.15 & 0.09 \\
25 & 11.60 & 6.53 & 12.11 & 32.90 & 10.80 & 93.74 & 26.33 & 4.28 & 0.40 & 0.87 & 0.24 & 0.21 \\
50 & 15.33 & 7.63 & 13.30 & 43.99 & 13.74 & 105.1 & 38.17 & 6.10 & 0.73 & 1.02 & 0.32 & 0.35 \\
100 & 19.33 & 8.66 & 14.26 & 57.77 & 16.87 & 115.72 & 52.87 & 8.48 & 1.27 & 1.17 & 0.42 & 0.59 \\
200 & 23.53 & 9.59 & 15.04 & 74.81 & 20.21 & 125.84 & 70.88 & 11.58 & 2.16 & 1.31 & 0.54 & 0.96 \\
500 & 29.31 & 10.70 & 15.86 & 103.59 & 24.88 & 138.44 & 100.27 & 17.12 & 4.19 & 1.48 & 0.73 & 1.78 \\
1000 & 33.85 & 11.46 & 16.34 & 131.14 & 28.62 & 147.56 & 127.21 & 22.69 & 6.79 & 1.62 & 0.91 & 2.79 \\
2000 & 38.37 & 12.15 & 16.73 & 164.83 & 32.48 & 156.19 & 158.63 & 29.80 & 10.8 & 1.74 & 1.12 & 4.35 \\
5000 & 43.34 & 12.82 & 17.05 & 212.60 & 36.88 & 165.29 & 199.64 & 40.30 & 18.2 & 1.87 & 1.40 & 7.14 \\
10000 & 48.96 & 13.51 & 17.39 & 274.30 & 41.92 & 175.09 & 251.29 & 54.54 & 30.6 & 2.01 & 1.76 & 11.72 \\
Skew & -0.61 & -0.80 & -1.10 & 0.52 & -0.42 & -0.49 & -0.22 & 0.44 & 0.51 & -0.6 & 0.14 & -0.69 \\
\hline
\end{tabular}

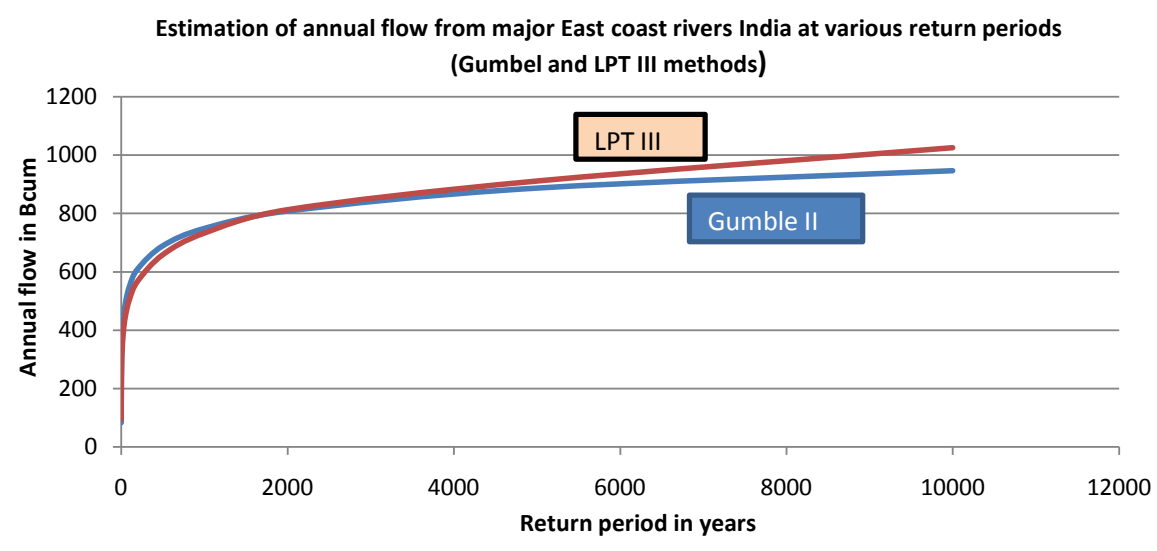

Figure 4. Total annual flow from major rivers in east coast of India (Gumble II and LPT III).

On comparison of predicted values at various recurrence intervals of total annual flow through the major rivers along east coast falling in the Bay of Bengal it is observed that Gumbel II method had lower values than LPT III method towards tail end. The forecasted values are almost same upto 4000 years of forecast Figure 5.

On comparison of the projected values of total annual sediment influx from the inland rivers along east coast, it is found Gumbel II method predict lower values of sediment at lower probabilities whereas LPT III method very high values. For design purposes of hydraulic structures Gumbel method may be accepted as projected sediment Figure 5. 


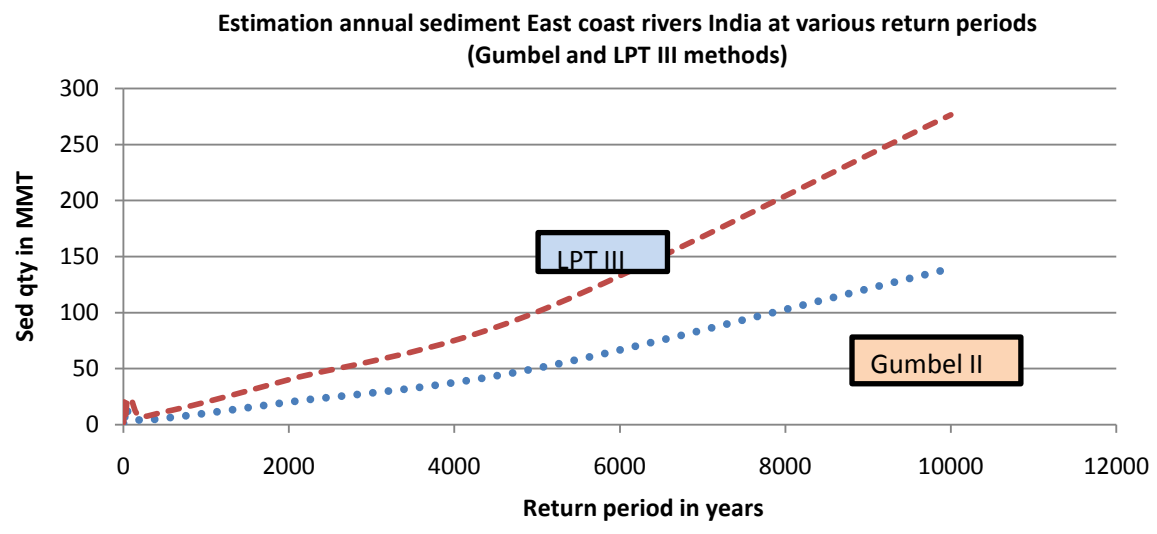

Figure 5. Total annual sediment influx from major rivers of EC of India to BoB (Gumble II and LPT III) [Estimation].

\section{Conclusions}

On study of major east flowing rivers along east coast of India and falling in Bay of Bengal, the following conclusions may be drawn:

1) All the east flowing rivers are emerging below the rift of Narmada valley and falling in Bay of Bengal forming large coastal plains, number of distributaries and encouraging huge sediment flow to the Bay of Bengal. The average annual flow and sediment at the delta head of the rivers are found to be $227.3 \mathrm{Bil}-$ lon Cum and 84.6 MMT respectively.

2) Erratic monsoon and hydrologic interventions have reduced sediment concentration of the rivers reaching delta head.

3) Regression analysis results of annual flow and sediment series had made a distinct division of peninsula Indian rivers above and below the Godavari River. The rivers flowing south of the river Godavari followed Gaussian model and the rivers above towards North East followed rational equations. The flow and the sediment influx are monsoon dependent.

4) Regression analysis of sediment influx time series follows Gaussian pattern towards south of Godavari river, but to the north, the sediment pattern does not obey any curve pattern, and $60 \%$ follow peak type equations except sediment flow of the Brahmani river.

5) The flow and sediment were projected by Gumbel II and Log Pearson III methods and observed both the methods gave almost equal predicted values for flow but for sediment forecast Gumbel II method gave lower values at various return periods.

From the above results, it can be inferred that for any structural design purposes, the Gumbel method projected values can be used for hydrologic study.

\section{References}

[1] Ministry of Water Resources. (2005) Govt. of India, Integrated Hydrological Data Book (Non-Classified Basins), Hydrological Data Directorate, Information Systems Organisation, Water Planning \& Projects Wing, Central Water Commission, New Delhi. 
[2] Kulkarni, J.R. and Srivastav, U.K. (1991) A Systems of Network of Marine Foods Industry in India, M. Visveswaraya Industrial Research and Development Centre, Bombay, IIM, Ahamadabad. Concept Publishing Company, New Delhi, 73-82.

[3] Chandramohan, P., Jena, B.K. and Sanil Kumar, V. (2001) Littoral Drift Sources and Sinks along the Indian Coast. Current Science, 81, 292-297.

[4] Mohapatra, M. and Subramanian, S.K. (2010) Interannual Variation of Frequency of Cyclonic Disturbances Landfalling over India. India Meteorological Department, New Delhi.

[5] Fuloria, R.C. (1993) Geology and Hydrocarbon Prospect of Mahanadi Basin, India. In: Biswas, S.K., et al., Eds., Proceedings of the 2 nd Seminar on "Petroliferous Basin in India”, Vol. 3, Indian Petroleum, Publication Dehra Dun, 355-369.

[6] Tandon, S.K. and Sinha, R. (2009) Geology of Large River Systems. In: Gupta, A., Ed., Large Rivers: Geomorphology and Management, John Wiley \& Sons, Ltd., New York, 7-28.

[7] Lal, N.K., Siawal, A. and Kaul, A.K. (2009) Evolution of East Coast of India-A Plate Tectonic Reconstruction. Journal of the Geological Society of India, 73, 249-260.

[8] Mahalik, N.K., Das, C. and Maejima, W. (1996) Geomorphology and Evolution of the Mahanadi Delta, India. Journal of Geosciences, 39, 3-122.

[9] Kumaran, K.P.N., Limay, R. and Padmalal, D. (2012) India's Fragile Coast with Special Reference to Late Quarterynary Dynamics. Proceeding of Indian National Science Academy, 78, 343-352.

[10] Kakani, N., et al. (2003) Reconstruction of the Late Holocene Progradation, Godavari Delta, India, a Preliminary Study. Transactions, Japanese Geomorphological Union, 24, 295-309.

[11] Prabakaran, K. and Anbarasu, K. (2010) Evolution of Vaigai Delta, Tamilnadu, India (East Coast) during Quaternary. International Journal of Geomatics and Geosciences, 1, 211-222.

[12] Sundaresh, Mani Murali, R., Seelam, J.K. and Gaur, A.S. (2014) Shoreline Changes along Tamilnadu Coast: A Study Based on Acrcheological and Coastal Dynamics Prospective. Indian Journal of marine Science, 43, 343-352.

[13] India-IWRS WIKI (2014) Water Resources Information of India, Last Modified. http://www.india-wris.nrsc.gov.in/wrpinfo/index.php

[14] Milliman, J.D. and Syvitski, J.P.M. (1992) Geomorphic/Tectonic Control of Sediment Discharge to the Ocean: The Importance of Small Mountainous Rivers. The Journal of Geology, 100, 525-544. https://doi.org/10.1086/629606

[15] Syvitski, J.P.M. and Morehead, M.D. (1999) Estimating River-Sediment Discharge to the Ocean: Application to the Eel Margin, Northern California. Marine Geology, 154, 13-28. https://doi.org/10.1016/S0025-3227(98)00100-5

[16] Zhou, Z. and Tong, Y. (2015) Case Study on Sediment Management and Wetland Conservation at Yellow River Mouth. The International Research and Training Center on Erosion and Sedimentation, Beijing.

[17] Gamage, N. and Smakhtin, V. (2009) Do River Deltas in East India Retreat? A Case Study of the Krishna Delta. Geomorphology, 103, 533-540. https://doi.org/10.1016/j.geomorph.2008.07.022

[18] Rao, K.N., Subraelu, P., Naga Kumar, K.Ch.V., Demudu, G., Hema Malini, B., Rajawat, A.S., et al. (2010) Impacts of Sediment Retention by Dams on Delta Shoreline Recession: Evidences from the Krishna and Godavari Deltas, India. Earth Surface 
Processes and Landforms, 35, 817-827. https://doi.org/10.1002/esp.1977

[19] Syvitski, J.P.M., Kettner, A.J., Overeem, I., Hutton, E.W.H.., Hannon, M.T., Brakenridge, G.R., Day, J., et al. (2009) Sinking Deltas Due to Human Activities. Nature Geoscience, Macmillan Publishers Limited, Basingstoke.

http://www.nature.com/naturegeoscience

[20] Syvitski, J.P.M. and Kettner, A. (2011) Sediment Flux and the Anthropocene. Philosophical Transactions of the Royal Society A: Mathematical, Physical and Engineering Sciences, 369, 957-975. https://doi.org/10.1098/rsta.2010.0329

[21] Gupta, H., Kao, S. and Dai, M. (2012) The Role of Mega Dams in Reducing Sediment Fluxes: A Case Study of Large Asian Rivers. Journal of Hydrology, 464, 447-458. https://doi.org/10.1016/j.jhydrol.2012.07.038

[22] Dandekar, P. (2014) Shrinking and Sinking Deltas: Major Role of Dams in Delta Subsidence and Effective Sea Level Rise. South Asia Network on Dams Rivers and People, 1-14.

[23] Sanil Kumar, V., Pathak, K.C., Pednekar, P., Raju, N.S.N. and Gowthaman, R. (2006) Coastal Processes along the Indian Coastline. Current Science, 91, 534.

[24] Vogel, R.M., Thomas, W.O. and McMahon, T.A. (1993) Flood-Flow Frequency Model Selection in Southwestern United States. Journal of Water Resources Planning and Management, 119, Paper No. 3787, 353-366. https://doi.org/10.1061/(ASCE)0733-9496(1993)119:3(353)

[25] Topalogu, F. (2002) Determining Suitable Probability Distribution Models for Flow and Precipitation Series of the Seyhan River Basin. Turkish Journal of Agriculture, 26, 189-194.

[26] Luo, P., He, B., Chaffe, P.L., Nover, D., Takara, K. and Mohd Remy Rozainy, M.A. (2013) Statistical Analysis and Estimation of Annual Suspended Sediments of Major Rivers in Japan. Environmental Science: Processes \& Impacts, 15, 1052-1061. https://doi.org/10.1039/c3em30777h

[27] Solomon, O. and Ogbeifun, P. (2013) Flood Frequency Analysis of Osse River Using Gumbel's Distribution. Civil and Environmental Research, 3, 55-59.

[28] Ghosh, K.G. and Mukhopadhyay, S. (2015) Hydro-Statistical Analysis of Flood Flows with Particular Reference to Tilpara Barrage of Mayurakshi River, Eastern India. ARPN Journal of Earth Sciences, 4, 76-88.

[29] Mishra, S.P. and Jena, J.G. (2015) Analytical Study of Monsoon Rainfall South Mahanadi Delta and Chilika Lagoon, Odisha. International Journal of Engineering and Technology (IJET), 7, 985-996.

[30] Central Water Commission, Ministry of Water Resources, Government of India (2006, 2007, 2009, 2012, 2015) Integrated Hydrological Data Book, (Non-Classified River Basins), Hydrological Data Directorate. Information Systems Organization, Water Planning \& Projects Wing, Central Water Commission, New Delhi.

[31] Al-Mashidani, G., Lal, P.B.B. and Fattah Mujd, M. (1978) A Simple Version of Gumbel's Method for Flood Estimation. Hydrological Sciences Bulletin, 23, 373-380. https://doi.org/10.1080/02626667809491810

[32] Mujere, N. (2011) Flood Frequency Analysis Using the Gumbel Distribution. International Journal on Computer Science and Engineering (IJCSE), 3, 2774-2779.

[33] Nnaji, G.A., Huang, W., Gitau, M.W. and Clark II, C. (2014) Frequency Analysis of Minimum Ecological Flow and Gage Height in Suwannee River, Florida. Journal of Coastal Research: Special Issue 68-Climate Change Impacts on Surface Water Systems, 152-159. https://doi.org/10.2112/SI68-020.1 